\title{
Quantifying Biodiversity Losses Due to Human Consumption: A Global-Scale Footprint Analysis
}

\author{
Harry C. Wilting, ${ }^{*}{ }^{\dagger}$ Aafke M. Schipper, ${ }^{\dagger}$ Michel Bakkenes, ${ }^{\dagger}$ Johan R. Meijer, ${ }^{\dagger}$ \\ and Mark A. J. Huijbregts ${ }^{\dagger,+}$ \\ ${ }^{\dagger}$ PBL Netherlands Environmental Assessment Agency, P.O. Box 30314, 2500 GH The Hague, The Netherlands \\ ${ }^{\ddagger}$ Department of Environmental Science, Institute for Water and Wetland Research, Radboud University, P.O. Box 9010,6500 GL \\ Nijmegen, The Netherlands
}

\section{Supporting Information}

ABSTRACT: It is increasingly recognized that human consumption leads to considerable losses of biodiversity. This study is the first to systematically quantify these losses in relation to land use and greenhouse gas (GHG) emissions associated with the production and consumption of (inter)nationally traded goods and services by presenting consumption-based biodiversity losses, in short biodiversity footprint, for 45 countries and world regions globally. Our results showed that (i) the biodiversity loss per citizen shows large variations among countries, with higher values when per-capita income increases; (ii) the share of biodiversity losses due to GHG emissions in the biodiversity footprint increases with income; (iii) food consumption is the most important driver of biodiversity loss in most of the countries and regions, with a global average of $40 \%$; (iv) more than $50 \%$ of the biodiversity loss associated with consumption in developed economies occurs outside their territorial boundaries; and (v) the biodiversity footprint per dollar consumed is lower for wealthier countries. The insights provided by our analysis might support policymakers in developing adequate responses to avert further losses of biodiversity when population and incomes increase. Both the mitigation of GHG emissions and land use related reduction options in production and consumption should be considered in strategies to protect global biodiversity.

\section{INTRODUCTION}

Global biodiversity is declining rapidly because of the ongoing and increasing anthropogenic impacts on the environment. ${ }^{1,2}$ Without adequate policy action, biodiversity is expected to decrease further. ${ }^{3-6}$ Current national policy strategies primarily focus on reducing biodiversity impacts within the country, for example by promoting more sustainable agriculture and forestry. ${ }^{7}$ However, effective strategies directed at averting global biodiversity loss must consider that consumption in a specific country or region may also cause considerable biodiversity loss elsewhere, via globally fragmented supply chains. ${ }^{8,9}$ Insights in consumption-based biodiversity losses, in short biodiversity footprints, offer starting points for policy to reduce global biodiversity loss. In particular, identification of the consumption categories, industries, and countries with the highest biodiversity impacts permits a prioritization that might be useful in policy strategies focusing on tackling global biodiversity loss. Such strategies include not only policy options directed at reducing biodiversity losses associated with specific industries in specific countries, for instance by improving production technologies, but also options to alter consumption patterns in countries all over the world. ${ }^{10}$

Environmentally extended multiregional input-output (EEMRIO) models are increasingly used to analyze tradedriven environmental pressures and resource requirements in consumption-based studies; for example, greenhouse gas (GHG) emissions, ${ }^{11}$ land use, ${ }^{12}$ material use, ${ }^{13}$ water use, ${ }^{14}$ and nitrogen emissions. ${ }^{15}$ EEMRIO models combine information on regional production structures with international trade data and therefore are particularly useful to trace pressures and impacts along supply chains. ${ }^{16,17}$ However, quantifying the biodiversity losses associated with these pressures and resource uses remains a significant challenge. Lenzen et al. ${ }^{9}$ calculated biodiversity footprints of nations based on red list species that were directly coupled to local production and linked to foreign consumption. Moran et al. ${ }^{18}$ applied the same approach to specific biodiversity-implicated supply chains, including nickel mining in New Caledonia, coltan from the Democratic Republic of Congo, cut flowers from Kenya, and forestry in Papua New Guinea. However, these authors did not explicitly model the cause-effect relationships between environmental pressures and biodiversity loss, as suggested by Hertwich. ${ }^{8}$ Introducing environmental pressures, such as GHG emissions and land use, provides a more explicit relationship between human drivers and biodiversity impacts. Identifying and quantifying these relationships informs consumers, producers and policymakers, and would help them in targeting adequate options and strategies to abate biodiversity loss.

Received: October 19, 2016

Revised: January 9, 2017

Accepted: January 10, 2017

Published: January 10, 2017 
Table 1. Attribution of Environmental Pressures and Biodiversity Impacts to Economic Sectors and Consumers ${ }^{a}$

\begin{tabular}{|c|c|c|c|}
\hline $\begin{array}{l}\text { environmental } \\
\text { pressure }\end{array}$ & biodiversity impacts due to & biodiversity loss factors & attributed to \\
\hline \multirow[t]{8}{*}{ land use } & habitat replacement by cropland (ha.yr) & MSA-loss per ha of cropland & crop sectors $(1-8)$ \\
\hline & habitat replacement by pasture (ha·yr) & MSA-loss per ha of pasture & livestock sectors $(9-12)$ \\
\hline & habitat replacement by forestry $(\mathrm{ha} \cdot \mathrm{yr})$ & MSA-loss per ha of forestry & forestry $(13)$ \\
\hline & habitat replacement by urban area (ha.yr) & MSA-loss per ha of urban area & consumers \\
\hline & fragmentation by cropland (ha.yr) & MSA-loss per ha of cropland & crop sectors $(1-8)$ \\
\hline & fragmentation by infrastructure $(\mathrm{km} \cdot \mathrm{yr})$ & MSA-loss'ha per $\mathrm{km}$ road length & all sectors (except agriculture) and consumers \\
\hline & disturbance by infrastructure $(\mathrm{km} \cdot \mathrm{yr})$ & MSA-loss.ha per $\mathrm{km}$ road length & all sectors (except agriculture) and consumers \\
\hline & encroachment (MSA-loss·ha·yr) & & consumers \\
\hline GHG emissions & climate change ( $\mathrm{kg} \mathrm{CO}_{2}$-equivalents) & MSA-loss'ha-yr per $\mathrm{kg} \mathrm{CO} \mathrm{CO}_{2}$-equivalents & all sectors and consumers \\
\hline
\end{tabular}

There are multiple environmental pressures underlying terrestrial biodiversity loss. ${ }^{19,20}$ Studies that quantified terrestrial biodiversity losses resulting from environmental pressures associated with the production and consumption of (inter)nationally traded goods and services focused on direct land-related impacts. ${ }^{21,22}$ Here, we expanded the number of pressures for biodiversity loss with other land-related impacts, such as fragmentation and disturbance by roads, and GHG emissions because these are generally recognized as major threats. ${ }^{4,23-25}$ We used the Mean Species Abundance (MSA) as an indicator of biodiversity. ${ }^{26,27}$ MSA expresses the mean abundance of original species in a disturbed situation relative to their abundance in undisturbed ecosystems, as a measure of the degree to which an ecosystem is intact. ${ }^{26}$

We specifically aimed to quantify the following: (i) the contributions of various consumption categories, such as housing, transport, food, goods, and services, to biodiversity footprints; (ii) the contributions of international trade and local pressures to biodiversity footprints, and (iii) the extent to which variation in biodiversity footprints is explained by primary anthropogenic drivers related to population and wealth.

\section{METHODS AND DATA}

2.1. EEMRIO Model. We based our analysis on an EEMRIO model that was used previously in research on carbon and land footprints. ${ }^{28}$ EEMRIO models, in general, distinguish three main elements: (i) consumption of various goods and services per country or region; (ii) production in industries all over the world required for this consumption; and (iii) local environmental pressures resulting from the production. We brought a fourth element in the model by quantifying and aggregating biodiversity losses resulting from the environmental pressures in each country or region (see Text Section S1 in the Supporting Information, SI). To that end, we quantified biodiversity loss factors expressing the loss in mean species abundance (MSA) per unit of land use (including infrastructure) or unit of GHG emissions.

Apart from supply chain-related biodiversity losses, consumers may have direct impacts on biodiversity, for example through recreation or hunting (encroachment), habitat replacement for housing, and GHG emissions resulting from heating or private transport. We calculated these direct biodiversity losses as well, attributed these directly to the consumers per region, and added these to the losses induced by expenditures as calculated with the EEMRIO model.

2.2. Model Parametrization. 2.2.1. Economic InputOutput Data. The EEMRIO model included 40 individual countries and five continent-based regions that covered the rest of the world (see Table S1 for a list of countries and regions). In each of the 45 countries and regions, 48 industries were distinguished (Table S2). We selected the World InputOutput Database (WIOD) ${ }^{29}$ as starting point for our model, as a direct follow up on our previous research on carbon and land footprints. $^{28}$

WIOD considers only one agricultural sector, whereas impacts on biodiversity may vary considerably among agricultural sectors. ${ }^{30}$ We therefore disaggregated the agricultural sector into 14 subsectors based on more detailed data from the GTAP database, version 8 (see Text Section S2). ${ }^{31}$ Furthermore, the WIOD covers 40 countries and only one Rest of the World (RoW) region. To add more detail, we disaggregated this RoW region into five major world regions also by using GTAP data (Rest of Oceania, Rest of America, Rest of Asia, Rest of Europe, and Africa) (see Text Section S2). At the time of this research, 2007 was the most recent year with GTAP data available. Therefore, we took this year as starting point to parametrize the EEMRIO model.

2.2.2. Environmental Pressures. We distinguished two main environmental pressures: land use (including infrastructure) and climate change induced by greenhouse gas emissions. Land use data were obtained from several databases. Crop areas were retrieved from the $\mathrm{FAO},{ }^{32}$ road data from the Global Roads Inventory Project (GRIP), ${ }^{33}$ and the areas of pasture, forestry and built-up land from the global terrestrial biodiversity model GLOBIO. ${ }^{26}$ Data on GHG emissions $\left(\mathrm{CO}_{2}, \mathrm{CH}_{4}\right.$, and $\left.\mathrm{N}_{2} \mathrm{O}\right)$ were obtained from WIOD and supplemented by data from $E \operatorname{CAR}^{34}$ and $\mathrm{UNFCC}^{35}$ for the agricultural subsectors. Cropland and GHG data were available for 2007; GLOBIO land use data per region were linearly interpolated between the closest earlier and later years (2005 and 2010) with data available.

Because land use and infrastructure affect biodiversity in different ways (direct impacts due to the eradication of natural habitat and indirect impacts including fragmentation, disturbance, and human encroachment of the remaining, surrounding natural habitat), we subdivided the land use and infrastructure pressures according to their effects and allocated these to specific sectors and/or directly to consumers (Table 1). Cropland, pasture, and forestry areas were allocated to the respective sectors. These areas included areas for subsistence farming and forestry, but we did not have data for allocating subsistence farming directly to consumers. Encroachment and urban areas were allocated directly to the consumers in a region/country. Encroachment impacts are due to recreation, gathering of berries, and hunting, which typically represent 
Table 2. Total (Million MSA-loss'ha·yr) and Per-Capita Biodiversity Footprints (MSA-loss·ha·yr) of 10 Countries/Regions in $2007^{a}$

\begin{tabular}{|c|c|c|c|c|c|c|}
\hline country & total footprint & footprint per capita & domestic share (\%) & import share (\%) & land use (\%) & GHG (\%) \\
\hline Africa & 668 & 0.7 & 94 & 6 & 90 & 10 \\
\hline China & 539 & 0.4 & 89 & 11 & 48 & 52 \\
\hline Europe & 811 & 1.4 & 70 & 30 & 55 & 45 \\
\hline India & 281 & 0.2 & 91 & 9 & 65 & 35 \\
\hline Japan & 138 & 1.1 & 46 & 54 & 48 & 52 \\
\hline North America & 977 & 2.2 & 83 & 17 & 58 & 42 \\
\hline Oceania & 162 & 4.6 & 89 & 11 & 78 & 22 \\
\hline Rest of Asia & 783 & 0.6 & 82 & 18 & 66 & 34 \\
\hline Russia & 348 & 2.4 & 92 & 8 & 77 & 23 \\
\hline South America & 539 & 1.2 & 94 & 6 & 80 & 20 \\
\hline World & 5246 & 0,8 & 100 & 0 & 66 & 34 \\
\hline
\end{tabular}

private activities of consumers. Urban areas, which include areas for housing, offices and factories, were directly assigned to the consumers in the region because of a lack of data for adequate allocation to production sectors. The length of roads in each region was distributed among sectors and consumers based on fuel use data for transport per region both for sectors and consumers. ${ }^{29}$ Fuel use for transport in agriculture is mainly for tractors and farming machinery that do not use public roads. Therefore, we excluded agriculture from the allocation of roads to sectors. More information on the environmental pressures (data and allocation to sectors) is provided as SI (Text Section S3).

2.2.3. Biodiversity Loss Factors. The translation from environmental pressures to biodiversity loss was based on biodiversity loss factors obtained from the GLOBIO model (version 3.5). ${ }^{36}$ GLOBIO calculates remaining biodiversity, expressed as the mean species abundance (MSA) of originally occurring species, in relation to various environmental pressures including climate change, land use and infrastructure. The model has a spatial resolution of $0.5^{\circ}$ by $0.5^{\circ}$. To obtain the land-related biodiversity loss factors (in MSA-loss.ha per unit of land use or roads), we first aggregated the pressurespecific MSA-losses, as calculated with the GLOBIO model, either per MRIO region (for land use and infrastructure pressures). Then, the aggregated loss in MSA due to a particular pressure was divided by the cumulative amount of that pressure, to arrive at the MSA-loss per ha of annual land use or $\mathrm{km}$ of road. Biodiversity loss factors for habitat replacement by cropland, pasture, forestry, and urban area were retrieved from the MSA values and areas of these land use types per region. Biodiversity loss factors for disturbance and fragmentation of natural habitat by roads were obtained from the respective MSA values combined with the road length per region, in order to determine the loss per kilometer of road length.

Biodiversity loss factors of GHG emissions (in MSA-loss ha. yr per $\mathrm{kg} \mathrm{CO}$-equivalents) were based on the time-integrated global temperature potential of GHG substances ${ }^{37}$ and the relationship between an increase in global mean temperature and losses in MSA per biome. ${ }^{38}$ On the basis of these relationships, we derived one average value for MSA-loss caused by global GHG emissions considering a time horizon of 100 years, consistent with IPCC. ${ }^{39}$ More details on the calculation of the loss factors are provided in Text Section S4.

2.2.4. Biodiversity Losses. All biodiversity impacts were expressed in MSA-loss.ha.yr reflecting the integration of impacts due to pressures over space and time. For land-related pressures, the time period is one year, implying that all land use in a specific year is held responsible for the total MSA loss due to land conversion. When production efficiencies and consumption do not change, the same MSA loss is accounted for in a next year preventing that the areas go back to a natural state. Biodiversity losses due to GHG emissions were modeled as potential losses in future years. The biodiversity footprint presented in this study is a composed indicator combining actual losses (based on observed patterns of species abundance) and future losses (based on predicted changes in species richness) due to pressures in one year; therefore, it does not reflect actual biodiversity losses in a particular year.

2.3. Identifying Ultimate Drivers of Biodiversity Footprints. We conducted a multiple regression analysis to relate the per-capita biodiversity footprints calculated for each of the 45 countries/regions to two possible explanatory variables: the per-capita expenditures (Purchasing Power Parity (PPP)-corrected), as a measure of wealth, and the human population density. Population density was chosen as a proxy for resource use efficiency, based on the assumption that a higher population density results in less land available for producing and extracting resources; thus, technology development is stimulated to use resources efficiently. In addition, when less natural areas are available for producing and extracting resources, this might lead to the need to use more imports. $^{13}$

We retrieved the total human population size and the per capita expenditures for 2007 from the GTAP database ${ }^{31}$ and the total land surface area, needed for deriving population density, from the FAO. ${ }^{32}$ Data used in the regression analysis are provided in Table S1. We conducted the regression analysis for the overall per-capita biodiversity footprint per country/ region as well as per-capita footprints broken down according to (i) location of the pressures (domestic or abroad), (ii) pressure type (land use related or GHG emissions), and (iii) consumption category (housing, transport, food, goods and services). To calculate the footprints of individual consumption categories, we allocated each sector and each of the direct (i.e., not supply chain related) biodiversity impacts to these consumption categories (Text Section S5; Table S2, Table S3).

Prior to the regression analysis, we $\log 10$-transformed both the response and the explanatory variables in order to reduce skewness. Further, we assessed the correlation among the explanatory variables and found that they were largely uncorrelated (Pearson's $r$ of 0.05). To account for possible 
nonlinear relationships between the footprints and the explanatory variables, in particular potential leveling off of the effects of affluence or population density, we added the squared terms of both explanatory variables to our regression model. To prevent overfitting, we performed a stepwise variable selection procedure to identify the most parsimonious model, using the Akaike Information Criterion (AIC) as selection criterion, and allowing a quadratic term only if the corresponding linear term was also included. Finally, we used the regression models to assess the changes in the biodiversity footprints in relation to each of the explanatory variables separately, conditional on the mean of the other explanatory variable. To that end, we calculated the relative difference $d_{\mathrm{r}}$ in each footprint for each of the explanatory variables as follows:

$$
d_{\mathrm{r}}=\frac{\left|y_{1}-y_{2}\right|}{\frac{y_{1}+y_{2}}{2}}
$$

where $y_{1}$ and $y_{2}$ are the modeled biodiversity footprint values at both ends of the range of the explanatory variable of concern.

\section{RESULTS}

3.1. Biodiversity Footprints. Overall biodiversity footprints calculated as MSA losses per citizen showed large variation across countries and regions (Table 2, for all 45 countries/regions see Table S4). In Australia, the biodiversity footprint per citizen was 8-fold higher than that of the world average of $0.8 \mathrm{MSA}-$ loss $\cdot$ ha $\cdot y r$. High per-capita losses were also found for other rich countries, including Canada, Finland and the U.S.A. In China, India, and Indonesia, the per-capita footprints were far below the world average, due to the low consumption per inhabitant. From the individual countries considered, the U.S.A., China, and Russia contributed most to the total biodiversity footprint (i.e., aggregated across all countries/regions) (Table 2 and S4). Consumption in the U.S.A., with less than $5 \%$ of the world population, caused with 758 million MSA-loss-ha.yr more than $14 \%$ of the total aggregated biodiversity loss, whereas China accounted for $10 \%$ of this biodiversity loss (539 million MSA-loss-ha.yr) with $20 \%$ of the world population.

3.2. Environmental Pressures. Approximately two-thirds (66\%) of global biodiversity loss was caused by direct land use, such as agriculture (feed and food) and forestry, and indirect land use impacts, such as human encroachment. Indirect land use footprints were particularly high in large countries with low human population densities, such as Russia, Australia, Brazil, and Canada. The reason is that these countries have relatively large natural areas that were affected by encroachment and road disturbance. Biodiversity losses caused by disturbances and fragmentation from roads contributed about $9 \%$ globally. GHG emissions caused almost $34 \%$ of total biodiversity loss. Consumption-based GHG emissions in the relatively rich countries, such as South Korea, Taiwan, and Luxembourg, contributed more than $55 \%$ to their total biodiversity loss (see Table S4).

3.3. Consumption Categories. For most of the countries/ regions, food consumption showed the highest contribution to the biodiversity footprint (Figure 1; for individual countries see Table S4); this was not only the case for low-income countries in which food accounted for more than $40 \%$ of the biodiversity footprint, but also for Australia with relatively high land-related biodiversity losses due to food consumption (Table S5). For India and Mexico, the share of food in the biodiversity footprint

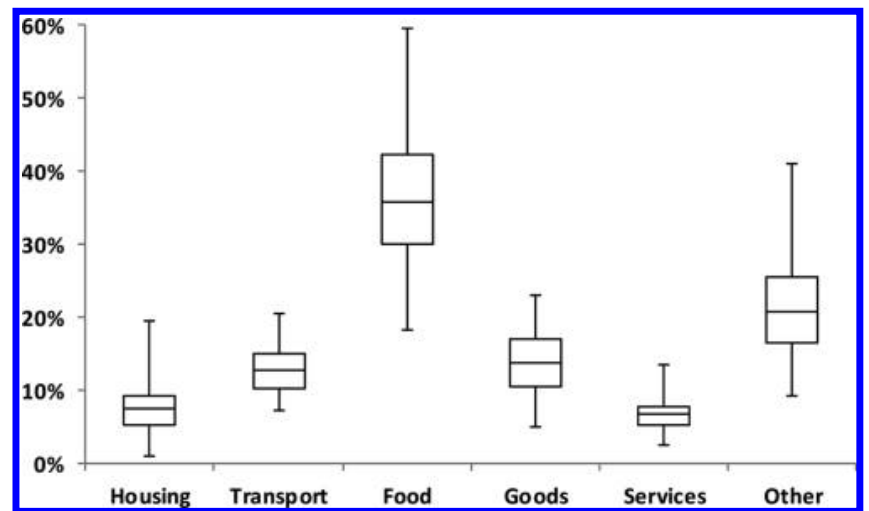

Figure 1. Contribution of different categories of consumption to total biodiversity loss due to GHG emissions and land use. Boxes show the first and third quartiles (25-75\%), and whiskers show the ranges for 45 countries/regions. The consumer demand for each of the 48 industries was aggregated to six main consumption categories, i.e., housing, transport, food, goods, services and other consumption; "other" includes category "Not allocated" (see SI, Text Section S5 and Table S3).

exceeded 50\%. All nonfood consumption categories showed lower shares in biodiversity losses due to less dependency on land use. In all countries and regions, biodiversity loss caused by consumption of services was relatively low, despite a high share of services in expenditures in some countries.

3.4. Trade in Biodiversity Loss. For 14 of the 45 countries/regions, environmental pressures outside their territory caused more than half of the biodiversity footprint. These were mainly small countries with a high demand for import of products from agriculture and forestry, such as Luxemburg, Belgium, The Netherlands, Malta, Japan, South Korea, and Taiwan (Table S4). For large countries, such as Brazil, Russia, India, Australia, China, and Indonesia, the share of foreign biodiversity losses in the biodiversity footprint was much lower (less than 15\%), because these countries were more self-sufficient in producing food products and other consumer goods. At a more aggregated level, Europe, North America, and Japan imported far more biodiversity loss than they exported (Figure 2a; Table S5). For the Rest of Asia, losses due to imports and exports were in balance. For the other six countries and regions shown in Figure 2a, biodiversity losses due to environmental pressures in their territory were higher than their biodiversity footprints, and these regions, including China, South America, and Africa, exported their biodiversity losses to other regions, such as North America and Europe. Approximately half of the exported losses from environmental pressures in Africa was the result of European consumption. Land-related biodiversity losses dominated the trade flows (Figure 2b). Approximately $20 \%$ of biodiversity loss caused by GHG emissions was due to trade between 10 world regions (Figure 2c). Trade in biodiversity losses de to GHG emissions between North America and Europe was almost in balance.

3.5. Ultimate Drivers of Biodiversity Footprints. Our regression analysis resulted in regression models with adjusted $R^{2}$ values ranging from 0.68 to 0.93 (Figure S1, Table S7), indicating that affluence (per-capita expenditures) and population density together accounted for the major part of the variation in per-capita biodiversity footprints among the countries/regions. Overall, positive relationships were found for affluence, whereby the increase tended to level off for all 


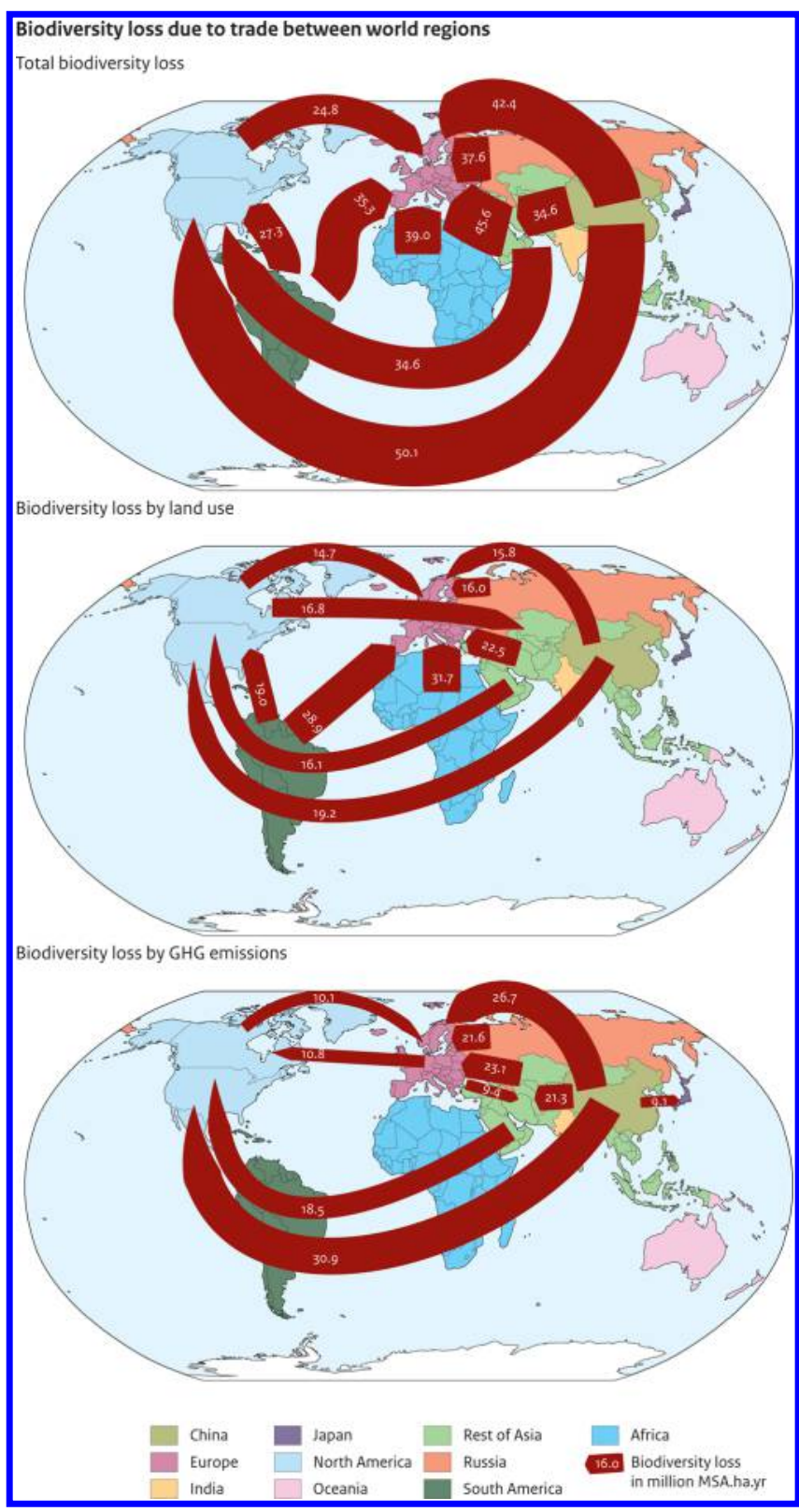

Figure 2. $(\mathrm{a}-\mathrm{c})$ Trade in biodiversity loss among 10 world regions and countries, and for the primary pressure categories (total, land use, and GHG emissions). Each part shows the ten trade flows causing the highest losses. The arrows start in the regions where the pressures take place and end in the consuming regions. Losses are measured in million MSA-loss $\cdot$ ha $\cdot y r$.

biodiversity footprints except the one related to services (Figure 3a, Table S7). The leveling-off of the total biodiversity footprint when expenditures increase implicates that richer countries have lower biodiversity losses per dollar consumed (in terms of PPP-corrected US dollars). Biodiversity footprints imported from abroad were most sensitive to increases in affluence $\left(d_{\mathrm{r}}\right.$ of $1.9)$, whereas biodiversity footprints related to domestic production were least sensitive ( $d_{\mathrm{r}}$ of 0.8 ; Figure $\left.3 \mathrm{a}\right)$. Among the consumption categories, the biodiversity footprint related to food consumption was least sensitive to increases in affluence. This indicates that increasing wealth is primarily directed toward import and consumption categories other than food. For population density, we found mostly negative responses of the footprints, except for the biodiversity footprint imported from abroad (no relationship; Figure 3b, Table S7). This indicates that countries/regions with less land available per person are likely to be more resource-efficient rather than relying on more imports. The domestic footprint was most sensitive to increases in population density $\left(d_{\mathrm{r}}\right.$ of 1.8$)$. Within the different categories of consumption, the steepest negative relationship $\left(d_{\mathrm{r}}\right.$ of 1.5$)$ was found between population density and the transport-related biodiversity footprint, which reflects the larger transport distances through natural areas in more sparsely populated countries/regions.

\section{DISCUSSION}

4.1. Limitations. With our analysis we demonstrated the feasibility of building a biodiversity footprint model based on pressure-impact relationships. In parametrizing the model, we used data from various sources and made several assumptions on applying them. First, we chose the WIOD, but other MRIO databases could be applied as well and updating and improving these databases is an ongoing process. MRIO databases are characterized by the number of sectors, products, and regions they identify. Compared to other MRIO databases, the number of sectors in the WIOD is relatively low and therefore, our model is less appropriate for conclusions on specific consumer products. A more detailed sector and product classification, which is available in Eora ${ }^{40}$ and EXIOBASE, ${ }^{41}$ enables investigations of biodiversity implicated supply chains of specific consumer products. ${ }^{18}$ Furthermore, the regional classification of WIOD is biased to developed rich countries and large economies, implying that WIOD is less representative of specific developing countries with relatively large biodiversity hotspots. Employing MRIO databases with more spatial detail, such as Eora ${ }^{40}$ and GTAP, ${ }^{42}$ would help to test the robustness of our conclusions.

Second, we limited our analysis to land-use related pressures and climate change, which led to an underestimation of the biodiversity footprints. For example, pollution and introduction of exotic species are other pressures that cause terrestrial biodiversity loss. ${ }^{19,20}$ Nevertheless, the proportion of threatened species affected by habitat change is more than twice the proportion of threatened species affected by other drivers. ${ }^{19,25}$ Further, Alkemade et al. ${ }^{26}$ confirmed a relatively low contribution of nitrogen deposition in most regions. Moreover, Oita et al. ${ }^{15}$ showed that global nitrogen emissions are driven by food-related consumption in the wealthier countries and that developed countries are net importers of nitrogen emissions. Hence, the inclusion of nitrogen emissions in our analysis would have consolidated our primary conclusions on the high per-capita biodiversity footprint in more prosperous countries and the importance of food in those footprints. Third, our study focuses on terrestrial biodiversity, but extension to aquatic biodiversity is required in order to relate consumption with overall biodiversity losses. Adding aquatic biodiversity might change the biodiversity footprint of some countries significantly, for instance for countries with high fish diets such as Japan. For including pressures and impacts related to freshwater biodiversity, data from the aquatic module of the GLOBIO model might be useful; ${ }^{43}$ for including marine biodiversity, other sources must be investigated.

4.2. Interpretation. We systematically quantified biodiversity losses in relation to land use and greenhouse gas (GHG) emissions associated with the production and consumption of (inter)nationally traded goods and services among 45 countries and world regions globally. Our results revealed that 


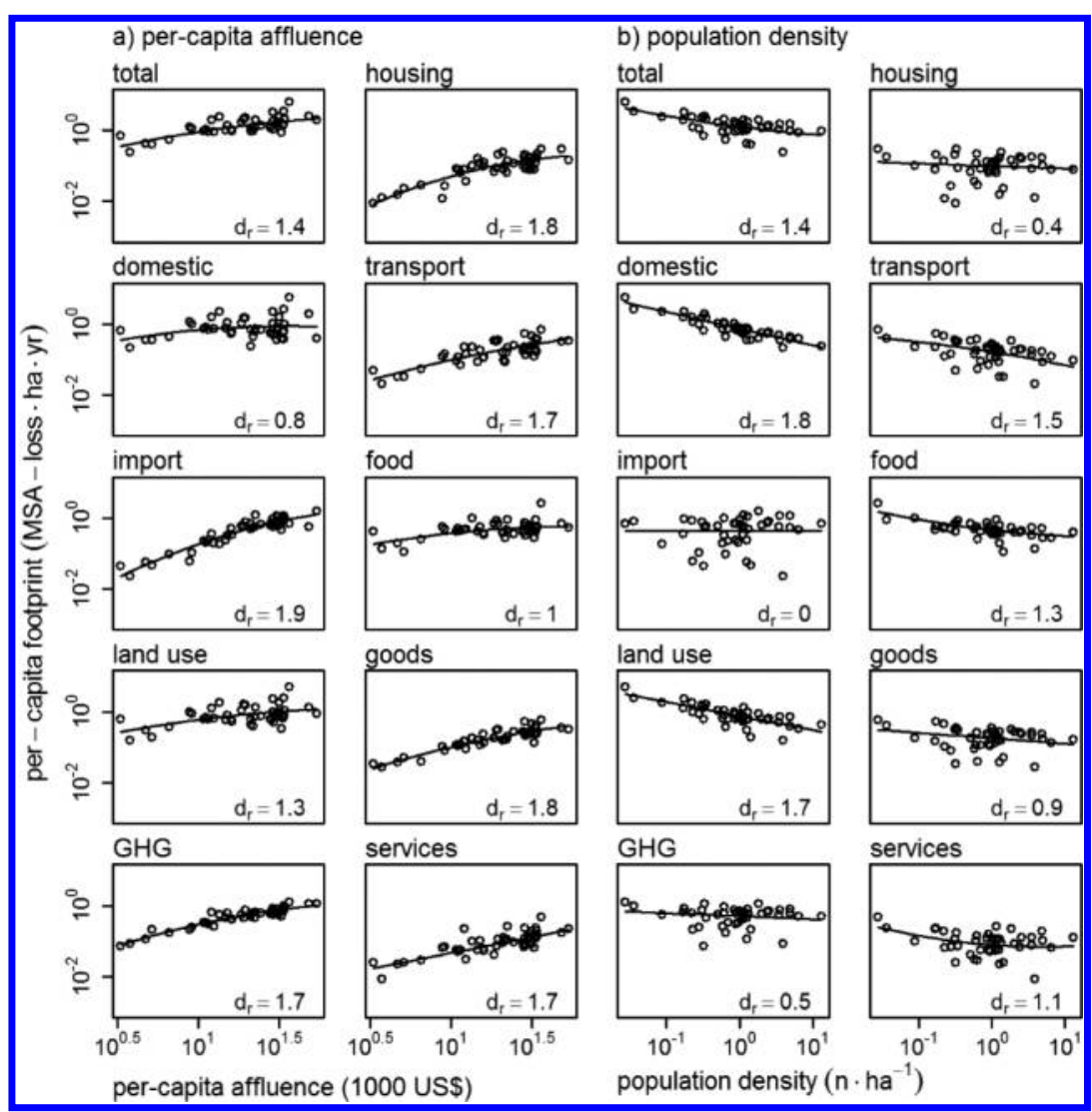

Figure 3. Partial response plots showing the per-capita biodiversity footprints in relation to (a) per-capita affluence and (b) population density. Relationships for per-capita affluence are conditional on the mean value of the population density across the 45 countries/regions, and vice versa. Relative differences $d_{\mathrm{r}}$ in biodiversity footprints across the ranges of the explanatory variables were calculated according to eq 1 .

biodiversity losses are not equally distributed. Rich countries have relatively high biodiversity footprints per capita, although the per-dollar biodiversity loss is lower than that in less prosperous countries and regions. Our results also indicated that increases in per-capita expenditures lead to the consumption of more nonfood goods and services (Figure $3 a)$, which result in a higher share of biodiversity losses caused by GHG emissions compared to food consumption (see Table S5).

Our regression analysis showed an increase in the land use based biodiversity footprint when incomes rise (Figure $3 b$ ). This is in line with the findings of Weinzettel et al., ${ }^{12}$ who found that the per capita land footprint of nations increases by a third when income doubles. One of the primary causes of biodiversity loss is land use for agriculture and forestry for food production and living materials, respectively. Production of animal protein, including use of cropland for feed, has a relatively high impact on biodiversity. ${ }^{44-46}$ Rising incomes lead mainly to an increase in the consumption of commodities from nonfood categories, such as transport, goods, and services, that cause substantial land-related biodiversity losses as well.

Our finding that the land-related biodiversity footprint per capita is higher for sparsely populated countries is supported by Weinzettel et al. ${ }^{12}$ who reported a higher land footprint for countries with more per-capita available bioproductive land area (biocapacity). Our finding that developed countries and regions, such as Japan, Europe, and North America, displace part of their land-related biodiversity footprint to other countries is consistent with studies on the tele-connection between local consumption and global land use. ${ }^{47,48}$ Thus, although we included less developing countries in our analysis, our primary findings on the land-related part of the biodiversity footprint are consistent with the studies on land footprints that we discussed. However, the biodiversity footprint refines the land footprint (i.e., the area of land used) by considering different types and intensity of land use, such as crop production, encroachment, or infrastructure (see Table S4).

Our analysis of the trade in biodiversity impacts caused by climate change should have similar conclusions as studies on consumption-based emissions of GHGs, since we used one global MSA loss factor per kilogram $\mathrm{CO}_{2}$-equivalent emissions. We found that a wealthy region as Europe imports a considerable share of its per capita footprint related to GHG emissions. This is in line with the findings of Davis and Caldeira, ${ }^{49}$ who concluded that wealthy countries, such as France, Sweden, the U.K., and Austria, are primary importers of consumption-based emissions.

In our study, biodiversity footprints were measured as losses in MSA. Since MSA is only one out a long list of biodiversity indicators, ${ }^{1,50}$ it would be interesting to see if studies on footprints based on other biodiversity metrics lead to similar results. Lenzen et al. ${ }^{9}$ related global biodiversity losses to international trade and consumption by counting the number of threatened species. National threat records and threats due to imports and exports were reported for the top-ranking net importers and exporters. Similar to our results, Lenzen et al. ${ }^{9}$ reported that the U.S.A., the European Union, and Japan are the primary importers of biodiversity threats. They also reported that countries in biodiversity-rich tropical regions, such as Indonesia, Madagascar and Papua New Guinea, are the 
largest exporters of biodiversity threats, primarily related to agricultural, fishing and forestry industries, but due to lack of detail on developing countries, a comparison with the outcomes of our model was not possible.

Until now GLOBIO results have been used in territorialoriented studies only. Aggregating these data to country levels and applying them in a footprint approach gave new insights in the GLOBIO outcomes and identified some potential peculiarities, such as the high contributions of encroachment in some countries, such as Russia and Brazil.

4.3. Implications. In medium-variant projections, the United Nations ${ }^{51}$ projects strong growth in world population up to 9.7 billion people in 2050 ( $0.8 \%$ annual growth). With an annual growth in world GDP of almost $3 \%,{ }^{52}$ per capita income will increase with $2 \%$ per year in the coming decennia. Because biodiversity footprints are strongly correlated with population and income, further biodiversity loss seems unavoidable, although higher population densities might decelerate the increase in losses (Figure $3 \mathrm{~b}$ ). Our results showed that with an increase in affluence biodiversity losses due to import increase faster than domestic losses (Figure 3a). This not only obscures the link between consumption and biodiversity impacts, but also shows a decoupling between consumption and domestic biodiversity impacts. Furthermore, losses due to GHG emissions, which are more related to nonfood goods and services, increase faster than land-use related losses with increasing incomes. Therefore, the mitigation of GHG emissions should be considered in strategies to protect global biodiversity next to land-use related strategies.

The projections of population and income imply that without drastic policy actions directed at conserving biodiversity further biodiversity loss seems unavoidable. Biodiversity footprints based on explicitly pressure-impacts relationships offer a variety of starting points for policy to reduce global biodiversity loss. The outcomes of our analysis are a first step by informing policy makers on countries, industries, and consumption categories with the highest impacts on biodiversity. Such a prioritization helps policy makers in defining options for protecting biodiversity. Possibilities to reduce biodiversity loss can be identified with various actors in different parts of supply chains. Our results showed a large share of consumption of food in the biodiversity footprint in relation to substantial contributions of losses from cropland and pasture. This solicits for options in the agro-production chain directed at production with lower impacts in combination with consumer-side options, for instance alternative diets with lower shares of animal proteins. Moreover, investigations of alternative diets in which both land-related and GHG-related biodiversity impacts are considered would extend on existing studies on the consequences for land use of changes in diets. ${ }^{53}$ For countries with high shares of impacts from forestry areas in their biodiversity footprint, options can be searched in comparing alternative wood-production techniques, for instance intensive forest plantation versus extensive low-impact logging, or in using other materials in construction with probably higher GHG emissions. More detailed information on the underlying drivers of encroachment per country is required to define reduction options for this pressure. However, for all analyses of the impacts of reduction options or adequate comparisons of alternative technologies or consumption patterns, models with sufficient detail are required.

Options directed at reducing specific environmental pressures and footprints might have unintended trade-offs, ${ }^{54}$ and a biodiversity footprint approach including multiple pressures as proposed in this study can identify some of these unexpected effects. For example, policies directed to reduce GHG emissions might increase land use, for example because of biofuel production or solar power plants. This implies a shift from future biodiversity impacts to current impacts. Biodiversity footprint indicators relating local production and pressures to consumption all over the world can be used to point out such trade-offs.

\section{ASSOCIATED CONTENT}

\section{Supporting Information}

The Supporting Information is available free of charge on the ACS Publications website at DOI: 10.1021/acs.est.6b05296.

Detailed descriptions of the environmentally extended multiregional input-output model, and the economic input-output, environmental, and biodiversity data used in this study. Tables on the explanatory variables per country used in the regression analysis, the allocation of economic sectors, environmental pressures, and biodiversity losses to consumption categories, characteristics of GHGs in relation to biodiversity impacts, and calculated biodiversity footprints (totals per country and shares of consumption categories and environmental pressures). One table and one figure with additional results on our regression analysis are also included (PDF)

\section{AUTHOR INFORMATION}

\section{Corresponding Author}

*Phone: +31 6469251 87; e-mail: Harry.Wilting@pbl.nl (H.C.W.).

\section{ORCID ${ }^{\circ}$}

Harry C. Wilting: 0000-0002-2330-8820

\section{Notes}

The authors declare no competing financial interest.

\section{ACKNOWLEDGMENTS}

We are very grateful to our PBL colleagues Ben ten Brink and Mark van Oorschot for their contributions in discussions on calculating biodiversity footprints. We thank Allard Warrink from PBL for preparing Figure $2 a-c$. Finally, we wish to thank the three anonymous referees for their constructive comments.

\section{REFERENCES}

(1) Butchart, S. H. M.; Walpole, M.; Collen, B.; van Strien, A.; Scharlemann, J. P. W.; Almond, R. E. A.; Baillie, J. E. M.; Bomhard, B.; Brown, C.; Bruno, J.; Carpenter, K. E.; Carr, G. M.; Chanson, J.; Chenery, A. M.; Csirke, J.; Davidson, N. C.; Dentener, F.; Foster, M.; Galli, A.; Galloway, J. N.; Genovesi, P.; Gregory, R. D.; Hockings, M.; Kapos, V.; Lamarque, J.-F.; Leverington, F.; Loh, J.; McGeoch, M. A.; McRae, L.; Minasyan, A.; Morcillo, M. H.; Oldfield, T. E. E.; Pauly, D.; Quader, S.; Revenga, C.; Sauer, J. R.; Skolnik, B.; Spear, D.; StanwellSmith, D.; Stuart, S. N.; Symes, A.; Tierney, M.; Tyrrell, T. D.; Vié, J.C.; Watson, R. Global Biodiversity: Indicators of Recent Declines. Science 2010, 328 (5982), 1164-1168.

(2) Dirzo, R.; Young, H. S.; Galetti, M.; Ceballos, G.; Isaac, N. J. B.; Collen, B. Defaunation in the Anthropocene. Science 2014, 345 (6195), 401-406.

(3) CBD. Global Biodiversity Outlook 4; Secretariat of the Convention on Biological Diversity: Montréal, 2014.

(4) Newbold, T.; Hudson, L. N.; Hill, S. L. L.; Contu, S.; Lysenko, I.; Senior, R. A.; Borger, L.; Bennett, D. J.; Choimes, A.; Collen, B.; Day, 
J.; De Palma, A.; Diaz, S.; Echeverria-Londono, S.; Edgar, M. J.; Feldman, A.; Garon, M.; Harrison, M. L. K.; Alhusseini, T.; Ingram, D. J.; Itescu, Y.; Kattge, J.; Kemp, V.; Kirkpatrick, L.; Kleyer, M.; Correia, D. L. P.; Martin, C. D.; Meiri, S.; Novosolov, M.; Pan, Y.; Phillips, H. R. P.; Purves, D. W.; Robinson, A.; Simpson, J.; Tuck, S. L.; Weiher, E.; White, H. J.; Ewers, R. M.; Mace, G. M.; Scharlemann, J. P. W.; Purvis, A. Global effects of land use on local terrestrial biodiversity. Nature 2015, 520 (7545), 45-50.

(5) Pereira, H. M.; Leadley, P. W.; Proença, V.; Alkemade, R.; Scharlemann, J. P. W.; Fernandez-Manjarrés, J. F.; Araújo, M. B.; Balvanera, P.; Biggs, R.; Cheung, W. W. L.; Chini, L.; Cooper, H. D.; Gilman, E. L.; Guénette, S.; Hurtt, G. C.; Huntington, H. P.; Mace, G. M.; Oberdorff, T.; Revenga, C.; Rodrigues, P.; Scholes, R. J.; Sumaila, U. R.; Walpole, M. Scenarios for Global Biodiversity in the 21st Century. Science 2010, 330 (6010), 1496-1501.

(6) Tittensor, D. P.; Walpole, M.; Hill, S. L. L.; Boyce, D. G.; Britten, G. L.; Burgess, N. D.; Butchart, S. H. M.; Leadley, P. W.; Regan, E. C.; Alkemade, R.; Baumung, R.; Bellard, C.; Bouwman, L.; BowlesNewark, N. J.; Chenery, A. M.; Cheung, W. W. L.; Christensen, V.; Cooper, H. D.; Crowther, A. R.; Dixon, M. J. R.; Galli, A.; Gaveau, V.; Gregory, R. D.; Gutierrez, N. L.; Hirsch, T. L.; Höft, R.; JanuchowskiHartley, S. R.; Karmann, M.; Krug, C. B.; Leverington, F. J.; Loh, J.; Lojenga, R. K.; Malsch, K.; Marques, A.; Morgan, D. H. W.; Mumby, P. J.; Newbold, T.; Noonan-Mooney, K.; Pagad, S. N.; Parks, B. C.; Pereira, H. M.; Robertson, T.; Rondinini, C.; Santini, L.; Scharlemann, J. P. W.; Schindler, S.; Sumaila, U. R.; Teh, L. S. L.; van Kolck, J.; Visconti, P.; Ye, Y. A mid-term analysis of progress toward international biodiversity targets. Science 2014, 346 (6206), 241-244.

(7) UNEP. Convention on Biological Diversity; National Biodiversity Strategies and Action Plans; last accessed October, 23, 2015. www.cbd. int/nbsap/default.shtml.

(8) Hertwich, E. Biodiversity: Remote responsibility. Nature 2012, 486 (7401), 36-37.

(9) Lenzen, M.; Moran, D.; Kanemoto, K.; Foran, B.; Lobefaro, L.; Geschke, A. International trade drives biodiversity threats in developing nations. Nature 2012, 486 (7401), 109-112.

(10) Hoekstra, A. Y.; Wiedmann, T. O. Humanity's unsustainable environmental footprint. Science 2014, 344 (6188), 1114-1117.

(11) Hertwich, E. G.; Peters, G. P. Carbon footprint of nations: A global, trade-linked analysis. Environ. Sci. Technol. 2009, 43 (16), 6414-6420.

(12) Weinzettel, J.; Hertwich, E. G.; Peters, G. P.; Steen-Olsen, K.; Galli, A. Affluence drives the global displacement of land use. Global Environmental Change 2013, 23 (2), 433-438.

(13) Wiedmann, T. O.; Schandl, H.; Lenzen, M.; Moran, D.; Suh, S.; West, J.; Kanemoto, K. The material footprint of nations. Proc. Natl. Acad. Sci. U. S. A. 2015, 112, 6271-6276.

(14) Lenzen, M.; Moran, D.; Bhaduri, A.; Kanemoto, K.; Bekchanov, M.; Geschke, A.; Foran, B. International trade of scarce water. Ecological Economics 2013, 94, 78-85.

(15) Oita, A.; Malik, A.; Kanemoto, K.; Geschke, A.; Nishijima, S.; Lenzen, M. Substantial nitrogen pollution embedded in international trade. Nat. Geosci. 2016, 9 (2), 111-115.

(16) Wiedmann, T. Impacts Embodied in Global Trade Flows. In Taking Stock of Industrial Ecology; Clift, R; Druckman, A., Eds.; Springer International Publishing: Cham, 2016; pp 159-180.

(17) Wiedmann, T.; Wilting, H. C.; Lenzen, M.; Lutter, S.; Palm, V. Quo Vadis MRIO? Methodological, data and institutional requirements for multi-region input-output analysis. Ecological Economics 2011, 70 (11), 1937-1945.

(18) Moran, D.; Petersone, M.; Verones, F. On the suitability of input-output analysis for calculating product-specific biodiversity footprints. Ecol. Indic. 2016, 60, 192-201.

(19) Pereira, H. M.; Navarro, L. M.; Martins, I. S. Global Biodiversity Change: The Bad, the Good, and the Unknown. Annual Review of Environment and Resources 2012, 37, 25-50.

(20) Spangenberg, J. H. Biodiversity pressure and the driving forces behind. Ecological Economics 2007, 61 (1), 146-158.
(21) Chaudhary, A.; Pfister, S.; Hellweg, S. Spatially Explicit Analysis of Biodiversity Loss Due to Global Agriculture, Pasture and Forest Land Use from a Producer and Consumer Perspective. Environ. Sci. Technol. 2016, 50 (7), 3928-3936.

(22) Kitzes, J.; Berlow, E.; Conlisk, E.; Erb, K.; Iha, K.; Martinez, N.; Newman, E. A.; Plutzar, C.; Smith, A. B.; Harte, J. Consumption-Based Conservation Targeting: Linking Biodiversity Loss to Upstream Demand through a Global Wildlife Footprint. Conservation Letters 2016, 1-8.

(23) Bellard, C.; Bertelsmeier, C.; Leadley, P.; Thuiller, W.; Courchamp, F. Impacts of climate change on the future of biodiversity. Ecology Letters 2012, 15 (4), 365-377.

(24) Thomas, C. D.; Cameron, A.; Green, R. E.; Bakkenes, M.; Beaumont, L. J.; Collingham, Y. C.; Erasmus, B. F. N.; Ferreira De Siqueira, M.; Grainger, A.; Hannah, L.; Hughes, L.; Huntley, B.; Van Jaarsveld, A. S.; Midgley, G. F.; Miles, L.; Ortega-Huerta, M. A.; Peterson, A. T.; Phillips, O. L.; Williams, S. E. Extinction risk from climate change. Nature 2004, 427 (6970), 145-148.

(25) Maxwell, S. L.; Fuller, R. A.; Brooks, T. M.; Watson, J. E. Biodiversity: The ravages of guns, nets and bulldozers. Nature 2016, $536,143-145$.

(26) Alkemade, R.; van Oorschot, M.; Miles, L.; Nellemann, C.; Bakkenes, M.; ten Brink, B. GLOBIO3: A Framework to Investigate Options for Reducing Global Terrestrial Biodiversity Loss. Ecosystems 2009, 12 (3), 374-390.

(27) Chaplin-Kramer, R.; Sharp, R. P.; Mandle, L.; Sim, S.; Johnson, J.; Butnar, I.; Milà i Canals, L.; Eichelberger, B. A.; Ramler, I.; Mueller, C.; McLachlan, N.; Yousefi, A.; King, H.; Kareiva, P. M. Spatial patterns of agricultural expansion determine impacts on biodiversity and carbon storage. Proc. Natl. Acad. Sci. U. S. A. 2015, 112 (24), $7402-7407$.

(28) Wilting, H. C. Carbon and land footprint time series of the Netherlands - integrating data from the GTAP and WIOD databases, $22^{\text {nd }}$ International Input-Output Conference. Lisbon, Portugal. www. iioa.org/conferences/22nd/papers/files/1630_20140509031_Paper_ Wilting_Lisbon.pdf.

(29) Timmer, M. P.; Dietzenbacher, E.; Los, B.; Stehrer, R.; de Vries, G. J. An Illustrated User Guide to the World Input-Output Database: the Case of Global Automotive Production. Review of International Economics 2015, 23 (3), 575-605.

(30) Donald, P. F. Biodiversity Impacts of Some Agricultural Commodity Production Systems. Conservation Biology 2004, 18 (1), $17-38$.

(31) Narayanan, G.; Badri, A. A.; McDougall, R. Global Trade, Assistance, and Production: The GTAP 8 Data Base; Center for Global Trade Analysis, Purdue University: West Lafayette, Indiana, USA, 2012.

(32) FAO FAOSTAT. Food and Agriculture Organization of the United Nations, Rome, last accessed April, 10, 2015. http://faostat3. fao.org/faostat-gateway/go/to/home/E.

(33) Meijer, J. R. The Global Roads Inventory Project (GRIP), online viewer; last accessed March, 26, 2015. http://geoservice.pbl.nl/ website/grip/.

(34) JRC and PBL EDGAR, Emission Database for Global Atmospheric Research, v4.2 EM CH4 300911 and v4.2_EM_N2O_111111; last accessed May, 2, 2013. http://edgar. jrc.ec.europa.eu/.

(35) UNFCCC GHG Data - Flexible queries, United Nations Framework Convention on Climate Change; last accessed May, 2, 2013. http://unfccc.int/di/FlexibleQueries/Event.do?event=go.

(36) Schipper, A.; Bakkenes, M.; Meijer, J.; Alkemade, R; Huijbregts, M. The GLOBIO Model. A technical description of version 3.5; PBL Netherlands Environmental Assessment Agency: The Hague, 2016.

(37) Joos, F.; Roth, R.; Fuglestvedt, J. S.; Peters, G. P.; Enting, I. G.; von Bloh, W.; Brovkin, V.; Burke, E. J.; Eby, M.; Edwards, N. R.; Friedrich, T.; Frölicher, T. L.; Halloran, P. R.; Holden, P. B.; Jones, C.; Kleinen, T.; Mackenzie, F. T.; Matsumoto, K.; Meinshausen, M.; Plattner, G. K.; Reisinger, A.; Segschneider, J.; Shaffer, G.; Steinacher, M.; Strassmann, K.; Tanaka, K.; Timmermann, A.; Weaver, A. J. 
Carbon dioxide and climate impulse response functions for the computation of greenhouse gas metrics: a multi-model analysis. Atmos. Chem. Phvs. 2013, 13 (5), 2793-2825.

(38) Arets, E. J. M. M.; Verwer, C.; Alkemade, R. Meta-Analysis of the Effect of Global Warming on Local Species Richness; Statutory Research Task Unit for Nature and the Environment. Wageningen University: Wageningen, The Netherlands, 2014.

(39) IPCC. Climate Change 2013: The Physical Science Basis. Contribution of Working Group I to the Fifth Assessment Report of the Intergovernmental Panel on Climate Change; Cambridge University Press: Cambridge, United Kingdom and New York, NY, USA, 2013.

(40) Lenzen, M.; Moran, D.; Kanemoto, K.; Geschke, A. Building Eora: A Global Multi-Region Input-Output Database at high Country and Sector Resolution. Economic Svstems Research 2013, 25 (1), 2049.

(41) Wood, R.; Stadler, K.; Bulavskaya, T.; Lutter, S.; Giljum, S.; de Koning, A.; Kuenen, J.; Schütz, H.; Acosta-Fernández, J.; Usubiaga, A.; Simas, M.; Ivanova, O.; Weinzettel, J.; Schmidt, J.; Merciai, S.; Tukker, A. Global Sustainability Accounting-Developing EXIOBASE for Multi-Regional Footprint Analysis. Sustainability 2015, 7 (1), 138163.

(42) Aguiar, A.; Narayanan, B.; McDougall, R. An Overview of the GTAP 9 Data Base. Iournal of Global Economic Analysis 2016, 1 (1), 181-208.

(43) Janse, J. H.; Kuiper, J. J.; Weijters, M. J.; Westerbeek, E. P.; Jeuken, M. H. J. L.; Bakkenes, M.; Alkemade, R.; Mooij, W. M.; Verhoeven, J. T. A. GLOBIO-Aquatic, a global model of human impact on the biodiversity of inland aquatic ecosystems. Environ. Sci. Policy 2015, 48, 99-114.

(44) Kissinger, G.; Herold, M.; De Sy, V. Drivers of Deforestation and Forest Degradation: A Synthesis Report for REDD+ Policymakers; Lexeme Consulting: Vancouver, Canada, 2012.

(45) Newbold, T.; Hudson, L. N.; Phillips, H. R. P.; Hill, S. L. L.; Contu, S.; Lysenko, I.; Blandon, A.; Butchart, S. H. M.; Booth, H. L.; Day, J.; De Palma, A.; Harrison, M. L. K.; Kirkpatrick, L.; Pynegar, E.; Robinson, A.; Simpson, J.; Mace, G. M.; Scharlemann, J. P. W.; Purvis, A. A global model of the response of tropical and sub-tropical forest biodiversity to anthropogenic pressures. Proc. $R$. Soc. London, Ser. $B$ 2014, 281 (1792), 1-10.

(46) Sala, O. E.; Stuart Chapin, F., III; Armesto, J. J.; Berlow, E.; Bloomfield, J.; Dirzo, R.; Huber-Sanwald, E.; Huenneke, L. F.; Jackson, R. B.; Kinzig, A.; Leemans, R.; Lodge, D. M.; Mooney, H. A.; Oesterheld, M.; LeRoy Poff, N.; Sykes, M. T.; Walker, B. H.; Walker, M.; Wall, D. H. Global biodiversity scenarios for the year 2100. Science 2000, 287, 1770-1774.

(47) Yu, Y.; Feng, K.; Hubacek, K. Tele-connecting local consumption to global land use. Global Environmental Change 2013, 23 (5), 1178-1186.

(48) Chen, G. Q.; Han, M. Y. Global supply chain of arable land use: Production-based and consumption-based trade imbalance. Land Use Policy 2015, 49, 118-130.

(49) Davis, S. J.; Caldeira, K. Consumption-based accounting of CO2 emissions. Proc. Natl. Acad. Sci. U. S. A. 2010, 107 (12), 5687-5692.

(50) Curran, M.; de Baan, L.; De Schryver, A. M.; van Zelm, R.; Hellweg, S.; Koellner, T.; Sonnemann, G.; Huijbregts, M. A. J. Toward Meaningful End Points of Biodiversity in Life Cycle Assessment. Environ. Sci. Technol. 2011, 45 (1), 70-79.

(51) United Nations. World Population Prospects: The 2015 Revision, Key Findings and Advance Tables; United Nations, Department of Economic and Social Affairs, Population Division: New York, 2015.

(52) OECD. GDP long-term forecast (indicator). doi: 10.1787/ d927bc18-en (Accessed on 05 January 2017).

(53) Kastner, T.; Rivas, M. J. I.; Koch, W.; Nonhebel, S. Global changes in diets and the consequences for land requirements for food. Proc. Natl. Acad. Sci. U. S. A. 2012, 109 (18), 6868-6872.

(54) Hertwich, E. G. Consumption and the Rebound Effect: An Industrial Ecology Perspective. I. Ind. Ecol. 2005, 9 (1-2), 85-98. 